\title{
SICKNESS ABSENCE AMONG RAILWAY CLERICAL STAFF
}

\author{
BY \\ DEREK S. PUGH, CECIL GORDON, and KATHERINE LÉVY \\ From the Department of Public Health and Social Medicine, Usher Institute, Edinburgh
}

(RECEIVED FOR PUBLICATION DECEMBER 31, 1958)

\begin{abstract}
This paper examines in detail the sickness absence experience within one well-defined railway occupation, identified in a previous paper for further study, namely clerks. The clerks consist of three hierarchical grades. The differences between them are described. The measures of sickness absence are identical with those of the previous communication. A gradient of sickness experience between the three grades is demonstrated. This occurs in inverse relation to the amount of responsibility associated with the posts. The gradient is accounted for by a small number of diagnostic categories. The implication of this is discussed. Comparisons are made with a similar population in London Transport and the results discussed. It is concluded that psychological factors might provide some explanation of the striking differences in sickness experience operating within one sub-class of the Registrar General's classification (IIIc) and within a limited salary scale.
\end{abstract}

In a previous communication (Gordon, Emerson, and Pugh, 1959b) the patterns of sickness absence among Scottish railwaymen were discussed and certain characteristics of occupations (grades) were examined in relation to the amount of sickness absence experienced. This paper examines further the characteristic of "responsibility" and its relation to the sickness patterns of three hierarchical railway grades. The terms used here are the same as those defined in the previous communication.

\section{Clerical Staff}

Among the occupations contained in the railway research population (see previous paper) is that of clerical staff, which is represented by three hierarchical grades, namely chief clerk, senior clerk, and clerk. These distinctions were given to us by the Scottish Regional Establishment and Staff Officer and his colleagues and were described to us as follows:-

A chief clerk exercises a considerable measure of responsibility, is sedentary, and has supervisory duties over other clerks.

A senior clerk does more or less routine work but requiring some measure of initiative, is sedentary, and is normally required to supervise small numbers of clerks.

Clerks require little or no initiative, are sedentary, and do routine work in all departments.

The clerical staff form a homogeneous group in that entry to the higher grades is entirely by promotion from the lower ones. The salaries of railway clerical staff may be noted. They currently range from $£ 540$ to $£ 731$ per annum depending on the responsibility of the individual post, but not only on supervisory responsibility. Thus a clerk doing specialized and important work may be paid as much as a chief clerk.

\section{Sickness Absence}

During the course of the general analysis of the sickness absence data a particular relationship between these grades was discovered. It was found that on all but one of the measures used chief clerks had less sickness absence than senior clerks, who in turn had less than clerks.

In order to make the data on the grades more comparable it was decided to limit the group to clerical staff aged 45 and over, since there are few chief clerks or senior clerks below this age. The data for the clerical staff aged $45+$ were agestandardized by the "direct" method (Hill, 1955) and are presented in Table 1 . In fact, because of the comparability in age range, age-standardization had very little effect on the actual rates and none at all on the relationship between the grades.

It will be seen that the chief clerks have a smaller number of sickness episodes; these involve a smaller number of people and there are fewer days lost per person during the year. Even when chief clerks 
TABLE 1

SICKNESS ABSENCE DATA FOR CLERICAL STAFF

\begin{tabular}{|c|c|c|c|c|c|c|c|}
\hline \multirow[b]{2}{*}{ Grade } & \multirow{2}{*}{$\begin{array}{l}\text { No. in } \\
\text { Group }\end{array}$} & \multirow{2}{*}{$\begin{array}{l}\text { Episode } \\
\text { Rate }\end{array}$} & \multirow{2}{*}{$\begin{array}{c}\text { Sick } \\
\text { Person } \\
\text { Rate }\end{array}$} & \multicolumn{3}{|c|}{ Average Duration } & \multirow{2}{*}{$\begin{array}{l}\text { Average No. of } \\
\text { Episodes per } \\
\text { Sick Person }\end{array}$} \\
\hline & & & & $\begin{array}{c}\text { Per Person } \\
\text { (Days Lost in Year) }\end{array}$ & $\begin{array}{c}\text { Per Episode } \\
\text { (Days) }\end{array}$ & $\begin{array}{c}\text { Per Sick Person } \\
\text { (Days Lost) }\end{array}$ & \\
\hline $\begin{array}{l}\text { Chief clerk } \\
\text { Senior clerk } \\
\text { Clerk }\end{array}$ & $\begin{array}{l}177 \\
391 \\
692\end{array}$ & $\begin{array}{l}0.52 \\
0.58 \\
0.65\end{array}$ & $\begin{array}{l}0.36 \\
0.38 \\
0.44\end{array}$ & $\begin{array}{r}7 \cdot 10 \\
10 \cdot 68 \\
13 \cdot 14\end{array}$ & $\begin{array}{l}14 \cdot 67 \\
18 \cdot 28 \\
20 \cdot 18\end{array}$ & $\begin{array}{l}20 \cdot 21 \\
21 \cdot 97 \\
29 \cdot 89\end{array}$ & $\begin{array}{l}1.43 \\
1.59 \\
1.49\end{array}$ \\
\hline
\end{tabular}

have a sickness episode, its average duration is shorter. The days lost per sick person are fewer and so are the number of episodes per sick person. All this is so in relation to both the lower grades of clerical staff. The same holds good for senior clerks in relation to clerks, except for a slight departure in the number of episodes per sick person.

Percentage Incidence of Types of Episodes.-In the previous paper it was found that the increase in the amount of sickness for the older age groups is accompanied by a change in the pattern of episode durations and we must now therefore consider whether the larger amount of sickness in clerks involves a similar change of pattern. Table 2 gives the percentage incidence of types of episodes for the three grades.

TABLE 2

PERCENTAGE INCIDENCE OF TYPES OF EPISODE IN CLERICAL STAFF

\begin{tabular}{l|c|c|c}
\hline $\begin{array}{c}\text { Length of Episode } \\
\text { (days) }\end{array}$ & $\begin{array}{c}\text { Chief Clerks } \\
(\%)\end{array}$ & $\begin{array}{c}\text { Senior Clerks } \\
(\%)\end{array}$ & $\begin{array}{c}\text { Clerks } \\
(\%)\end{array}$ \\
\hline Uncertified (1 to 2) & 37 & 30 & 32 \\
Casual (3 to 6) & 20 & 15 & 16 \\
Short (7 to 24) & 25 & 34 & 30 \\
Medium (25 to 72) & 12 & 16 & 15 \\
Long (73 +) & 85 & 55 & 74 \\
N & 87 & 232 & 444 \\
\hline \multicolumn{3}{|c|}{$\mathrm{N}=100 \%$}
\end{tabular}

The pattern appears to be very much the same for senior clerks and clerks. Compared with both of these there is a tendency for chief clerks to have a somewhat higher percentage of uncertified and casual episodes (57\% as compared with 45 and 48) and a correspondingly lower percentage of the remaining types. Thus the differences between chief clerks and the others appear to be due to a lower incidence of episodes of more than one week's duration. This is confirmed by a consideration of
TABLE 3

EPISODE RATES FOR CLERICAL STAFF

\begin{tabular}{l|c|c|c}
\hline \multicolumn{1}{c|}{ Episodes } & Chief Clerks & Senior Clerks & Clerks \\
\cline { 1 - 2 } Uncertified & $0 \cdot 19$ & $0 \cdot 18$ & $0 \cdot 20$ \\
Casual & $0 \cdot 10$ & $0 \cdot 09$ & $0 \cdot 10$ \\
Short & $0 \cdot 12$ & $0 \cdot 20$ & $0 \cdot 19$ \\
Medium & 0.06 & $0 \cdot 09$ & $0 \cdot 10$ \\
Long & 0.02 & 0.03 & 0.04 \\
\hline
\end{tabular}

the episode rate for different durations in Table 3.

In general it will be seen from Table 3 that clerks have a higher episode rate for all durations (except short) but particularly so for long episodes.

Age Trends in Sickness Absence.-It is also interesting, when comparing the three clerical grades, to consider the age trends in each. Table 4 and Fig. 1 give the average duration per person by age for the clerical staff. The differences between the grades are shown most strikingly on this measure. At each age, rates correspond in ascending magnitude to the hierarchical order.

Clerks show the normal rise with age; the tendency to level off in the oldest age group may be due to the separation of sick workers from the labour force. (Considering the average duration per person for the whole railway research population given in the previous communication, it will be seen that the shape of the curve for age groups 45 to 64 is very similar to that for clerks.) Chief clerks appear to be less prone to sickness absence in that their curve lies entirely below that of the other grades, but there is a very steep rise in the earlier age groups and a sharp decline in the later ones. The rise may be due to the fact that at these ages, fairly soon after they have been promoted, the chief clerks find their adaptation to the job hardest, and thus produce a higher sickness rate. The fall at the older ages may be due to a proportionately greater withdrawal

TABLE 4

AVERAGE NUMBER OF DAYS PER PERSON LOST IN YEAR

\begin{tabular}{|c|c|c|c|c|c|c|c|c|c|c|}
\hline \multirow{3}{*}{ Grade } & \multicolumn{8}{|c|}{ Age Groups (Years) } & \multirow{2}{*}{\multicolumn{2}{|c|}{ Total }} \\
\hline & \multicolumn{2}{|c|}{45 to 49} & \multicolumn{2}{|c|}{50 to 54} & \multicolumn{2}{|c|}{55 to 59} & \multicolumn{2}{|c|}{60 to 64} & & \\
\hline & No. & Rate & No. & Rate & No. & Rate & No. & Rate & No. & Rate \\
\hline $\begin{array}{l}\text { Chief clerk } \\
\text { Senior clerk } \\
\text { Clerk }\end{array}$ & $\begin{array}{r}30 \\
53 \\
144\end{array}$ & $\begin{array}{r}2.73 \\
7 \cdot 08 \\
11 \cdot 11\end{array}$ & $\begin{array}{r}46 \\
138 \\
287\end{array}$ & $\begin{array}{r}7 \cdot 70 \\
9 \cdot 03 \\
11 \cdot 49\end{array}$ & $\begin{array}{r}69 \\
150 \\
204\end{array}$ & $\begin{array}{r}9.80 \\
13.71 \\
15.22\end{array}$ & $\begin{array}{l}32 \\
50 \\
57\end{array}$ & $\begin{array}{r}4 \cdot 00 \\
12 \cdot 94 \\
15 \cdot 74\end{array}$ & $\begin{array}{l}177 \\
391 \\
692\end{array}$ & $\begin{array}{r}7.00 \\
11 \cdot 06 \\
12.87\end{array}$ \\
\hline
\end{tabular}




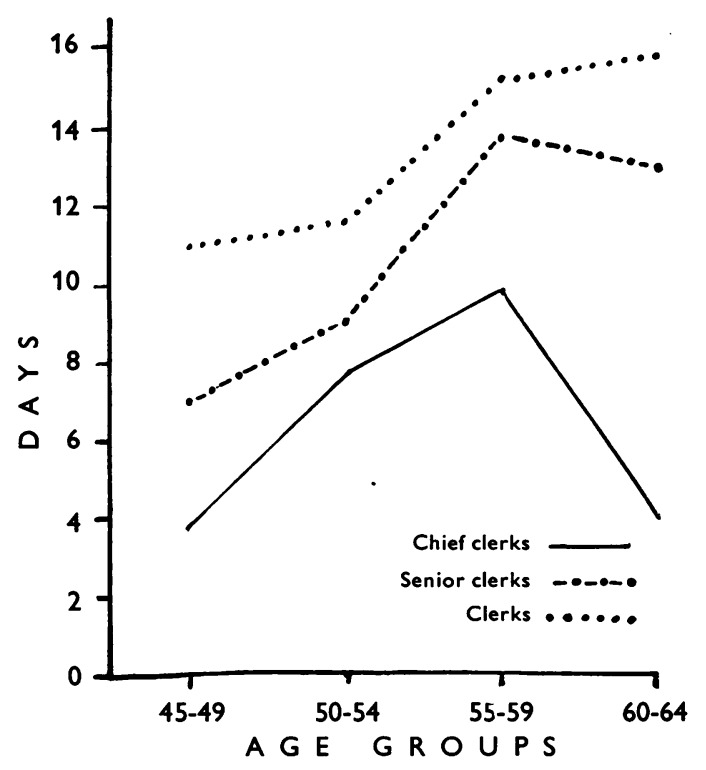

FIG. 1.-Average duration per person (days lost in the year).

from work due to sickness or death than in the other grades. The same considerations may apply but with less force to the intermediate grade of senior clerk. The numbers are small, and some of the results, e.g., the low rate of chief clerks at ages 45-49, might be due, partially at least, to chance.

It is obvious that in addition to age, the length of time in present grade is relevant to this discussion, but to add this as another variable would so attenuate the numbers in the sub-groups as to make the rates very unreliable.

Diagnosis.-For each sickness episode we have available a diagnosis obtained from the doctor's certificate which a man must present when his absence is of three days or longer. When an absence is of only one or two days' duration we have the man's own "diagnosis" which is accepted as sufficient by the railway authorities. Within the limitations inherent in such data an analysis of the diagnoses was carried out.

All causes of sickness absence were broken down into broad diagnostic categories. The grouping of London Transport Executive (1956) was used in order to make direct comparison with their results, and because it appeared suitable for the limited examination which our information would permit.

The diagnostic categories in which a gradient exists were demonstrated by the use of the ratios clerk: senior clerk and senior clerk: chief clerk, using the measure of average duration per person. The gradient was shown to exist in six categories,
TABLE 5

AVERAGE DURATION OF SICKNESS ABSENCE PER PERSON IN DIFFERENT DIAGNOSTIC GROUPS

\begin{tabular}{|c|c|c|c|}
\hline \multirow{2}{*}{ Grades } & \multicolumn{2}{|c|}{ Diagnostic Groups } & \multirow{2}{*}{$\begin{array}{l}\text { Total } \\
\text { (days) }\end{array}$} \\
\hline & $\begin{array}{c}\text { *Special } \\
\text { (days) }\end{array}$ & $\begin{array}{l}\text { Other } \\
\text { (days) }\end{array}$ & \\
\hline $\begin{array}{l}\text { Chief clerk } \\
\text { Senior clerk } \\
\text { Clerk }\end{array}$ & $\begin{array}{l}2 \cdot 25 \\
5 \cdot 42 \\
7 \cdot 48\end{array}$ & $\begin{array}{l}4 \cdot 75 \\
5 \cdot 63 \\
5 \cdot 39\end{array}$ & $\begin{array}{r}7.00 \\
11.05 \\
12.87\end{array}$ \\
\hline
\end{tabular}

*(a) Functional nervous disorders, (b) bronchitis, (c) diseases of circulatory system, $(d)$ diseases of stomach and duodenum, $(e)$ accidents, $(f)$ diseases of bones and organs of movement.

namely: (a) functional nervous disorders, $(b)$ bronchitis, $(c)$ diseases of the circulatory system, $(d)$ diseases of the stomach and duodenum, $(e)$ accidents, and $(f)$ diseases of bones and organs of movement. It is shown in Table 5 that if these six categories are ignored, no gradient exists, and therefore these categories are responsible for the total gradient. We found no evidence of a gradient going in the opposite direction.

Definitions of Diagnoses.-It should be noted that "functional nervous disorders" include both psychotic and neurotic mental illness, and that in the category "bronchitis" no distinction is made between the acute and chronic forms.

"Diseases of the circulatory system" includes all heart conditions except congenital heart disease, all hypertensive heart disease, diseases of arteries and veins, as well as ill-defined symptoms referable to this system.

"Diseases of the stomach and duodenum" includes peptic ulcer and other diseases of the stomach and duodenum, but not carcinoma.

"Diseases of bones and organs of movement" includes arthritis and rheumatism, osteomyelitis and other diseases of bones and joints, but not rheumatic fever.

The category "accidents" presents a different problem as we did not make the distinction between accidents on and off duty that was made by London Transport. For purposes of comparison we have grouped their two categories together.

\section{Comparisons with London Transport Clerical and Technical Staff (Men)}

Comparisons with an apparently similar population in London Transport are given in Tables 6 and 7. London Transport regards all episodes of six months or more as being of six months only, and ignores all episodes of three days or less. For comparison our figures have been corrected on this basis.

We have also made corrections in the categories "common cold" and "influenza" to compensate for some obvious anomalies in our figures. In the first 
TABLE 6

COMPARISON OF SICKNESS RATES AND DURATION FOR CLERICAL STAFF OF THE RAILWAY RESEARCH POPULATION AND LONDON TRANSPORT

\begin{tabular}{|c|c|c|c|c|c|c|}
\hline \multirow{3}{*}{$\begin{array}{l}\text { Age Group } \\
\text { (years) }\end{array}$} & \multirow{2}{*}{\multicolumn{2}{|c|}{ Episode Rate }} & \multicolumn{4}{|c|}{ Average Duration } \\
\hline & & & \multicolumn{2}{|c|}{ Per Episode } & \multicolumn{2}{|c|}{ Per Person } \\
\hline & $\begin{array}{c}\text { Railway Research } \\
\text { Population } \\
\text { (days) }\end{array}$ & $\begin{array}{c}\text { London } \\
\text { Transport } \\
\text { (days) }\end{array}$ & $\begin{array}{c}\text { Railway Research } \\
\text { Population } \\
\text { (days) }\end{array}$ & $\begin{array}{l}\text { London } \\
\text { Transport } \\
\text { (days) }\end{array}$ & $\begin{array}{c}\text { Railway Research } \\
\text { Population } \\
\text { (days) }\end{array}$ & $\begin{array}{c}\text { London } \\
\text { Transport } \\
\text { (days) }\end{array}$ \\
\hline $\begin{array}{l}45 \text { to } 49 \\
50 \text { to } 54 \\
55 \text { to } 59 \\
60 \text { to } 64\end{array}$ & $\begin{array}{l}0.34 \\
0.37 \\
0.42 \\
0.37\end{array}$ & $\begin{array}{l}0.39 \\
0.41 \\
0.44 \\
0.48\end{array}$ & $\begin{array}{l}24 \cdot 65 \\
25 \cdot 17 \\
30 \cdot 51 \\
26 \cdot 81\end{array}$ & $\begin{array}{l}20 \cdot 19 \\
22 \cdot 78 \\
29 \cdot 21 \\
30 \cdot 81\end{array}$ & $\begin{array}{r}8 \cdot 36 \\
9 \cdot 23 \\
12 \cdot 84 \\
10 \cdot 03\end{array}$ & $\begin{array}{r}7 \cdot 79 \\
9 \cdot 36 \\
12 \cdot 71 \\
14 \cdot 76\end{array}$ \\
\hline
\end{tabular}

TABLE 7

AVERAGE DURATION OF SICKNESS PER PERSON FOR CLERICAL STAFF OF THE RAILWAY RESEARCH POPULATION AND LONDON TRANSPORT

\begin{tabular}{|c|c|c|c|c|c|c|}
\hline \multirow[b]{2}{*}{$\begin{array}{l}\text { Age Groups } \\
\text { (years) }\end{array}$} & \multicolumn{2}{|c|}{ Special Diagnostic Groups } & \multicolumn{2}{|c|}{ Other Groups } & \multicolumn{2}{|c|}{ Total } \\
\hline & $\begin{array}{c}\text { Railway Research } \\
\text { Population } \\
\text { (days) }\end{array}$ & $\begin{array}{l}\text { London } \\
\text { Transport } \\
\text { (days) }\end{array}$ & $\begin{array}{c}\text { Railway Research } \\
\text { Population } \\
\text { (days) }\end{array}$ & $\begin{array}{l}\text { London } \\
\text { Transport } \\
\text { (days) }\end{array}$ & $\begin{array}{c}\text { Railway Research } \\
\text { Population } \\
\text { (days) }\end{array}$ & $\begin{array}{c}\text { London } \\
\text { Transport } \\
\text { (days) }\end{array}$ \\
\hline $\begin{array}{l}45 \text { to } 49 \\
50 \text { to } 54 \\
55 \text { to } 59 \\
60 \text { to } 64\end{array}$ & $\begin{array}{l}2 \cdot 10 \\
5 \cdot 26 \\
8 \cdot 32 \\
6 \cdot 47\end{array}$ & $\begin{array}{l}3.55 \\
3.86 \\
6.92 \\
8.01\end{array}$ & $\begin{array}{l}6 \cdot 26 \\
3 \cdot 96 \\
4 \cdot 52 \\
3 \cdot 56\end{array}$ & $\begin{array}{l}4 \cdot 24 \\
5 \cdot 50 \\
5 \cdot 79 \\
6 \cdot 75\end{array}$ & $\begin{array}{r}8 \cdot 36 \\
9 \cdot 22 \\
12 \cdot 84 \\
10 \cdot 03\end{array}$ & $\begin{array}{r}7 \cdot 79 \\
9 \cdot 36 \\
12 \cdot 71 \\
14 \cdot 76\end{array}$ \\
\hline
\end{tabular}

all episodes of 28 days or over are regarded as of 28 days only, and in the second, all episodes of 42 days or over are regarded as of 42 days only.

From Table 6 it can be seen that the episode rate is lower, and the average duration per episode is higher in the railway research population than in London Transport. These figures bear out the different patterns of sickness absence already noted in the previous paper, though the clerks resemble each other more closely than do the groups as a whole. On the measure of average duration per person (Table 7), this resemblance is again marked.

Comparison of the special and other diagnostic groups by age with London Transport is given in Table 7. It can be seen that the average duration per person rises with áge in the special groups both in London Transport and in the railway research population, but there is no rise in the other groups in the railway research population, and only a slight rise in London Transport.

\section{Sickness Absence Effects on Promotion}

One of the major questions immediately posed by the above results is the following: Is it the absence of malfunction with attendant lack of sickness which leads to promotion, or does the failure to achieve promotion induce malfunction? It is clear that a consideration of the data derived from recording job changes in the railway research population would be relevant. Unfortunately, the available material relating to changing of job is only for the period of a year and covers a comparatively small number of changes with consequent relative unreliability of the measures. With this caution in mind it is presented here as a first estimate.

Of the 92 clerks who were promoted during the year, 28 had some form of sickness absence. This gives a sick person rate of 0.30 compared with 0.44 for all clerks. Similarly seven of the 21 senior clerks promoted had a sickness absence, giving a sick person rate of 0.33 compared with 0.38 for all senior clerks. Thus, as far as it goes, the available information supports the hypothesis that there is some medical factor involved in selection, although its precise degree has yet to be determined.

\section{Conclusions}

In this paper we have described the sickness absence experience of a specific occupational group (railway clerical staff) and have demonstrated that a gradient of sickness exists among its hierarchical grades. This gradient is inversely related to the amount of supervisory responsibility carried by the posts. Supervisory staffs are healthier than their subordinates of the same age as shown by such measures as the percentage of men who have a sickness absence during the year, and the number of days lost per person through sickness. Also the pattern of episode durations is different; chief clerks have a significantly higher percentage of shorter sickness absences of less than one week, and a correspondingly lower percentage of longer episodes.

We have also shown that the gradient is provided 
by a limited number of diagnostic categories which include functional nervous disorders, and diseases of the stomach and duodenum. These might suggest a psychosomatic element, although it is difficult to see how the remaining categories showing the gradient can be reconciled with this. It is clear that there are other factors at work.

From the point of view of social medicine the gradient demonstrated here is of particular interest since we are not measuring social class differences. The gradient operates within a very small salary range, among persons who all belong to class IIIc in the Registrar General's classification. We are tapping intra-class differences where such psychological factors as morale, attitude to work, and "absence threshold" become central. A closer examination of industrial groups which present a homogeneity otherwise difficult to obtain, might throw some light on disputed questions in the aetiology of diseases and especially on the common origin of seemingly separate diseases. We hope that other such studies as this will be forthcoming.
This work was started with encouragement from the Human Relations Committee of the Department of Scientific and Industrial Research and the Medical Research Council. We are grateful to the Medical Research Council for a grant in aid.

We are happy to acknowledge the very great help of the Establishment and Staff Office of the Scottish Region of British Railways through Mr. C. H. Brazier, Mr. D. F. Gowen, Mr. J. Weston, and Mr. D. Murray. We are grateful to Dr. W. A. R. Mailer and Dr. J. D. Galletly of the Medical Department. Thanks are also due to Mr. M. G. Bennet, Operational Research Division of the British Transport Commision.

The work has had the friendly interest of the trade unions concerned.

We have had much assistance from Gene McKinnon, Patricia Taylor, and Jane Walsh (research auxiliaries), John Nimmo (Hollerith technician), and Gertrude Cleary (clerk).

\section{REFERENCES}

Gordon, C., Emerson, A. R., and Pugh, D. S. (1959b). Brit. J. industr. Med., 16, 230.

Hill, A. Bradford (1955). Principles of Medical Statistics, 6th ed. The Lancet, London.

London Transport Executive (1956). Health in Industry. Butterworth, London 